\title{
TO THE PROBLEM OF CONSERVATION AND FUNCTIONING OF ETHNIC LANGUAGES IN THE POLYNATIONAL SOCIETY
}

\author{
Atirkul Agmanova1, Yevgeniya Zhuravleva², Dybys Tashimkhanova ${ }^{3}$, Elvira \\ Yavorskaya ${ }^{4}$, Damira Akynova ${ }^{5}$ \\ ${ }_{1}^{1}$ Prof. Dr., L.N. Gumilyov Eurasian National University, KAZAKHSTAN, agmanova@mail.ru \\ 2 Prof. Dr., L.N. Gumilyov Eurasian National University, KAZAKHSTAN, zhuravleva_ea@enu.kz \\ ${ }^{3}$ Associate Prof., Candidate of Phil. Sciences, L.N. Gumilyov Eurasian National Ūniversity, \\ KAZAKHSTAN, tdybys@mail.ru \\ ${ }^{4}$ Senior Lecturer, MA, L.N. Gumilyov Eurasian National University, KAZAKHSTAN, \\ ya_elvira@mail.ru \\ ${ }^{5}$ Senior Lecturer, PhD, L.N. Gumilyov Eurasian National University, KAZAKHSTAN, mirada- \\ 86@mail.ru
}

\begin{abstract}
The article investigates the problem of preservation and development of languages of ethnic groups living in Kazakhstan. Factors affecting the conservation and proper functioning of the native languages of ethnic groups, as well as development trends in terms of interaction with the state and Russian languages are considered on the example of Tatar and Polish.
\end{abstract}

Keywords: ethnicity, ethnic language retention, Tatar, Polish, multicultural society.

\section{INTRODUCTION}

The issue of the article arises due to a research interest in the language contacts in a multiethnic society, the topicality of studying the characteristics of language and ethnic identification and the processes of conservation and use of the native language and culture of representatives of various ethnic groups living in Kazakhstan, as well as the specificity of their interaction and mutual influence of the new geopolitical conditions.

The paper identifies the essential manifestation of linguistic and ethnic identity, especially their modification and development in the context of the changing language situation. The study is aimed at identifying factors affecting the conservation and proper functioning of the native languages of ethnic groups, as well as development trends in terms of interaction with the state and Russian languages on the background of dynamic ethno-demographic processes.

\section{THE LEGAL FRAMEWORK OF THE STATE SUPPORT OF PRESERVATION AND DEVELOPMENT OF NATIVE LANGUAGES IN THE REPUBLIC OF KAZAKHSTAN SECTION}

The Republic of Kazakhstan is a multinational and multilingual state, which is inhabited by representatives of more than 130 ethnic groups. The uniqueness of ethno-linguistic space of the country is determined not only by a high degree of linguistic diversity, but also the dominance of state Kazakh and Russian languages - the 
languages of the two major ethnic groups - in the social and communicative system of Kazakhstani society. The impact of historical and political factors, namely, the policy of widespread Russification carried out in the Soviet period, led to the development of mass Kazakh-Russian bilingualism, as well as the fact that for a long time, interaction between the numerous ethnic groups in the social, administrative, economic, cultural and other walks of life carried out mainly in Russian.

Trends in the operation and development of native languages in the modern multiethnic Kazakhstan reflect the state language policy and the result of modern language planning consistently pursued in the years of independence. The language policy is evaluated as "the most liberal in the whole post-Soviet space» (Suleimenova, 2011, p. 41), because it is not only aimed at ensuring the full functioning of the state language as an important factor in strengthening national unity, but also to support preservation and development of languages of other ethnic groups living in Kazakhstan.

The main directions of the language policy of sovereign Kazakhstan, which meet the needs of multi-ethnic population and take into account the demographic and political situation, is reflected in the basic legislative acts of the Republic of Kazakhstan: the Constitution of the Republic of Kazakhstan (Articles 7, 93) (Constitution, 2002), the Law «On languages in the Republic of Kazakhstan» (Law, 1999), Decrees and the annual Messages of the President of the country N.A. Nazarbayev. Over the years of the sovereignty the Republic of Kazakhstan adopted three state programmes of functioning and development of languages, i.e. «State program of functioning and development of languages in the Republic of Kazakhstan for 1998-2000» (State Program, 2002), «State program of functioning and development of languages in the Republic of Kazakhstan for 2001-2010» (State Program, 2005), "State program of development and functioning of languages in the Republic of Kazakhstan for 2011-2020» (State Program, 2011). As a result of the first two programs the legal basis of language development in the main areas of public life were formed, social and communicative functions of the state language were greatly expanded and strengthened, general cultural features of the Russian language were saved, the development of other languages of the peoples of Kazakhstan was supported. The «State program of development and functioning of languages in the Republic of Kazakhstan for 2011-2020» is currently in its implementation, which was adopted by Presidential Decree N 110 from June 29, 2011. The purpose of the Program lies in the harmonious language policy to ensure the full functioning of the state language as an important factor in strengthening national unity while preserving the languages of all ethnic groups living in Kazakhstan. In accordance with this purpose in the program specific tasks related to the consolidation of the linguistic capital of Kazakhstan's society are determined, which are associated not only with the development and improvement of the state language, but also the maintaining of the level of functioning of the Russian language in communicative language space of the country; the provision of state support for the preservation and development of native languages of the people of Kazakhstan:

«... The creation of favorable conditions for the study and preservation of the languages of ethnic groups living in Kazakhstan. Ways to achieve, and the system of measures:

1. Creation of conditions for education and training in schools, language courses, Sunday schools, schools of national revival of representatives of ethnic groups living in Kazakhstan

1.1. Providing training and methodological assistance (Ministry of Education and Science (MES), MC, local executive bodies (LEB))

1.2. Attracting experienced professionals-teachers, native speakers, using international experience and modern technologies in teaching native languages (MES, Assembly of Peoples of Kazakhsan (APK), MC, LEB)

2. Provision of the necessary conditions for the preservation of the languages and cross-enriching of ethnic cultures

2.1. The organization of cultural events (festivals, competitions, celebrations with demonstrations of customs and traditions of the people, etc.) (MK, APK, LEB)

2.2. Organization of outreach activities (information coverage of events involving the media, seminars, conferences, forums, language holidays of ethnic groups) for the development of the culture and languages of ethnic groups living in Kazakhstan (MK, APK, MSI, MFA, MES, LEB)

2.3. Ensuring the preservation of historical and contemporary written heritage of ethnic groups (archives, libraries, research)

(MK, APK, LEB)

2.4. The conclusion of the intergovernmental agreements on the organization of mutual visits and conducting 
activities (MFA, MC, APK)

\section{Promotion of the creative implementation of population}

3.1. Promoting the further implementation of the cultural and creative opportunities of ethnic groups (publication of printed materials, production of television broadcasts, the development of literature and art) (MSI, APK, MK, LEB) » (State Program, 2011).

As we see the developed program focuses on the methodological aspect of the problem, the use of conventional and development of innovative methods of language teaching. It is not surprising as Kazakhstan is a unique multi-ethnic environment, which requires different approaches to each language.

It should be noted that vigorous activity of the Assembly of Peoples of Kazakhstan established in 1995 at the initiative of the Head of State N.A. Nazarbayev plays a special role in the process of implementation of the state support to preserve the identity of ethnic groups and languages in a growing interest in diasporas to their native language, culture, traditions and customs of its people. In Kazakhstan, there are more than 820 ethnic and cultural associations.

\section{FUNCTIONING OF POLISH AND TATAR IN KAZAKHSTAN}

\subsection{The Tatar language}

Tatar diaspora in Kazakhstan is the sixth largest ethnic group in multinational Kazakhstan: native Tatar language people in the country are more than 200 thousand people. According to the census of 2009, the proportion of Tatars comprises $1.3 \%$ out of the total population. According to the last two censuses, population dynamics of the Tatar diaspora is as follows: 1999 - 248954 people; 2009 - 204229 people. Thus, a decrease in the proportion of representatives of the Tatar diaspora in Kazakhstan is $18 \%$. It should be noted that among the members of this ethnic group, the urban population (152,449 people) significantly exceeds the number of rural residents (51,780 people). In terms of regions of settlement Tatars are allocated in the northeastern region (Karaganda, East Kazakhstan, Kostanai, Pavlodar, Akmola, North Kazakhstan, South Kazakhstan, Almaty region and Almaty) (Census, 2010).

According to the 1999 census, 92.5 thousand Tatars (37.1\%) speak their native language, 158.3 thousand Tatars (63.6\%) speak Kazakh, 241.3 thousand Tatars (96.9\%) speak Russian (Languages of the Peoples of Kazakhstan, 2007, p. 211). According to the census of 2009, the native language to 104.2 thousand Tatars (51.1\%) is Tatar, about 100 thousand Tatars (48.9\%) chose other languages (Census, 2010).

The Association of Tatars and Bashkirs of Kazakhstan is actively functioning in Kazakhstan since 2007, whose members include about 30 legal organizations from all regions of Kazakhstan. The Association was accepted as a member of the International Union of Public Associations «World Tatar Congress» and has strong contacts with the relevant organizations throughout the world.

The multi-faceted activities of members of the Association of national-cultural associations is aimed at supporting the study and use of the ethnic language, development and promotion of cultural heritage: the opening of the Tatar Sunday schools in the regions of Kazakhstan; the opening of centers and museums of eminent personalities, representatives of the Tatar diaspora; publishing works of art, feature stories and reference books; strengthening the relations in the field of Education and Culture of the Republic of Tatarstan; preservation and promotion of national traditions; the annual holding of Sabantuy, the national holiday of Tatar people, in Kazakhstan at regional and national levels.

One of the well-known ethnic communities in the country is «Idel» - the Association of Tatar and Tatar-Bashkir social and cultural centers of Kazakhstan. Association «Idel» is working hard to revive and promote the Tatar and Bashkir culture, language and history of the people, the preservation of national traditions and customs. Particular attention is paid to the organization of scientific and practical conference on the preservation of the Tatar culture, celebrations of Sabantuy, the annual music festival «Melodies of the Irtysh River».

The scientific community of Kazakhstan and Tatarstan also contribute to preservation and development of the Tatar language and culture. So, since 2015 «Educational and Cultural Center of the Institute of Kayum Nasyri of Kazan Federal University» is functioning in Astana (the capital of Kazakhstan) on the basis of L.N. Gumilyov Eurasian National University designed to be a bridge to unite efforts in the promotion and popularization of the Tatar language and culture (Zamaletdinov, 2015, p. 5). The Center is developing master educational programs of double-diploma education on the «Philology» specialty, "Kazakh language and literature» specialty and «Tatar language and literature» specialty. 


\subsection{The Polish language}

According to the classification of languages of Kazakhstan on the number of ethnic groups, the largest native Polish language speakers in the country are more than ten thousand people. The largest compact settlements of Poles are located in North Kazakhstan, Akmola, Karaganda and Almaty regions. In Kazakhstan society «Węże» ("Contact») and the Union of Poles in Kazakhstan. Despite the harsh periods of life, the majority of Poles preserved national traditions, were able to pass love to the native songs, dances and culture to a new generation. The country has five Polish companies dealing with national and cultural revival. In the northern areas, in places where the Polish diaspora is mainly settled, satellite Polish TV «TV Polonia» is being broadcast

According to the 1999 census, 4.3 thousand Poles (9.1\%) speak their mother tongue, 4.7 thousand Poles (9.9\%) speak Kazakh, 46,8 thousand (98.9\%) speak Russian (Languages of the Peoples of Kazakhstan, 2007, p. 199). According to the 2009 census, 3.2 thousand Poles $(9.3 \%)$ named Polish as the mother tongue, about 30.9 thousand of them (90.7\%) - other languages (Census, 2010).

Sunday schools are functioning in Kokshetau and several villages of Akmola and North Kazakhstan regions, which are home to a large number of representatives of the Polish, which aim to communion population to polish culture and learning the Polish language. This form of training has had time to establish itself well and has a long term.

The youth dance ensemble "Stepovaya Kvyaty» has been functioning in Kokshetau for more than 10 years, showing their art not only in Kazakhstan, but also abroad. Children and students are actively studying the Polish language, go for a vacation to Poland. About 600 students from Kazakhstan are studying at universities in their historical homeland. Every year, universities in Poland accept to 90-100 students from the Kazakhstani Poles on free tuition, among them $20 \%$ are the Kazakhs, the Russians, the Koreans, the Ukrainians and other nationalities. Kazakhstani students study at universities in Poland in the framework of the presidential program «Bolashak».

One of the most important conditions for successful language development is the organization and ensurance of the stable operation of the full system of language training, which is an integral part of the general culture of society. It should be noted that in certain areas of compact residence of the population, representing one or another ethnic group, the language of these ethnic groups for a long time has been studied in two ways in schools and universities: as a foreign language and as a mother tongue, in particular, this applies to the German and Polish diaspora. All this gave positive results: the students received a good knowledge of the language that allowed them to take internships and semester studying in universities of these countries. Currently, due to the departure of the population, first of all, representatives of the German, Jewish and Polish nationalities to their historic homeland, the interest in language learning, especially as a mother tongue, has declined. Many classes and departments in universities were closed. Moving of Kazakhstani Poles in Poland has not had a mass character, however the process is still active and significantly affected the occupancy of Polish classes and, accordingly, reduced the demand for teachers of the Polish language and literature. In addition, in recent years the Polish language teachers are often advocate volunteers from Poland.

The first higher education institution in which the Polish language and literature has been studied as a specialty was Sh. Ualikhanov Kokshetau State University. The Polish branch of the Faculty of Philology at the University of Kokshetau was opened in 1991. The university has repeatedly invited experts from Poland for implementation of the educational process, who not only held classes, but also provided a stimulating environment for learning Polish. University he created all conditions for work (wages, housing, etc.).

From 1991 to 2006, more than 100 teachers of Polish language and literature were issued at Sh. Ualikhanov KSU for secondary schools having classes with the Polish language or planned elective classes on the Polish language. All graduates fulfilled course and degree works, bearing the scientific nature, participated in student research conferences, including Poland.

Polish in the northern region of Kazakhstan is taught in Kokshetau (school N 5), Schuchinsk (school N 3, 4, 6, 8), as well as in schools in Stepnogorsk, Shortandy and Astrakhan regions of Akmola region, in Tainsha, Chkalovo village, Kellerovka village and other North Kazakhstan regions. All these schools were provided by the teaching staff, trained in Sh. Ualikhanov Kokshetau State University. A good level of knowledge obtained by students, confirmed by further education of graduates in educational institutions in Poland. Unfortunately, the demand for specialists for the region decreased annually, and in 2007 there were no candidates for this specialty.

In 2006, with the support of the Consulate of Poland in Kazakhstan specialty «Philology: Polish Language and Literature» was opened on the basis of the Kazakh University of International Relations and World Languages 
(Zhuravlev, Piontek, 2013, p. 64-71).

In 2010, Center for Polish Language and Culture started functioning at the Faculty of Philology of L.N. Gumilyov ENU. The idea of opening the Centre belonged to the Polish Embassy, and was supported by the University. The center began to take shape and function from October 2010-2011 academic year, which was preceded by extensive work on the agreement between ENU and the Embassy of the Republic of Poland in Kazakhstan. To work at the Center for Ministry of Science and Higher Education directed teachers of the Polish language, masters of Polish Philology: Tomasz Piontek (2010-2013), Magdalena Zakrzewski (2013-2014), Malgorzata Begus (2014-2015). The center is equipped with an interactive whiteboard and other technical means necessary for the educational process, as well as textbooks, teaching aids and dictionaries that have been provided by the Embassy of the Republic of Poland in Kazakhstan.

It is very important to know not only its historical roots that is, mother tongue, but also modern related languages for the comprehension of language. In this case the modern Slavic language is the Polish. Beginning from the fall of 2010 , students of all specialties of university had the opportunity to learn Polish optionally, in 2011-2012 academic year Polish language course (elective course) is introduced into the educational program of the specialty «Russian language and literature» as one of the Slavic languages. The monitoring conducted by the Department of Theoretical and Applied Linguistics shows that the students are interested in learning the Polish language, and for several years now choose this discipline.

Several optional groups by levels of training: A0, A1, B1, B2 and C1, as well as students of II course of the specialty «Russian language and literature» are studying the Polish language in the center. Center for Polish Language and Culture is organizing a trip for summer courses, held in Warsaw, Krakow, and Lublin.

Some joint projects relating to educational activities and training of students, as well as allowing to expand the students' knowledge about Polish culture, is already underway.

It seems that the form of training the Polish language and literature can be quite varied.

Implementation of the State program of functioning and development of languages involves creating optimal sociolinguistic space in the country, determined to achieve the necessary ratio of functional languages used on the territory of Kazakhstan. All these measures are aimed at preserving and national identity of Poles in Kazakhstan.

\section{METHODOLOGY}

The study is based on experimental data (questionnaires, associative experiment and interviewing representatives of different ethnic groups). 50 representatives of the Tatar, Korean, Polish, Ingush nationalities participated in the survey within the framework of the pilot phase of the survey of representatives of different ethnic groups in Kazakhstan (April-May 2015). The survey is aimed at studying the processes of ethnic and linguistic identity, the national specific features of perception of the world, the specificity of the interaction of ethnic languages in the Kazakh, Russian and other languages, interaction and mutual influence of language consciousness of ethnic groups in a multicultural and polylingual Kazakhstani society.

The material for this article is based on some results of a pilot survey conducted among representatives of the Polish (Slavic group) and the Tatars (Turkic group). The results of the survey include issues on language competence of the Tatars and the Poles, their use of language in different social and communication spheres, forms of preservation and use of the native language and culture.

\section{RESULTS AND DISCUSSION}

The analysis of perception a language as a mother tongue revealed the following picture: 1) Tatars: $70.0 \%$ of respondents named Tatar as the native language, 16.7\% - Russian, 3,3\% - Kazakh, 10\% - indicated 2 languages as their mother tongue: Tatar and Russian; 2) the Polish respondents: $66.7 \%$ of respondents indicated Russian as their native language, 16.7\% - Polish, 16.6\% - indicated 2 languages as a mother tongue: Russian and Polish. Thus, we can state the fact of linguistic assimilation. It is expressed more among the Poles.

It must be noted that the identification data on a language with their nationality can be subjective and indicative and may show the desire of respondents to be reckoned to a particular ethnic group. However, the most objective picture can be obtained on the basis of indicators of the degree of fluency in the native language and the spread of bilingualism.

To determine the level of passive language skills we used the following formula: $b$ ) I understand it, but I cannot 
explain, c) I understand it and can hardly explain; and for active language use - d) I understand it, freely speak and read, but don't write, e) I understand it, freely speak, read and write. We also used the following statement - a) I don't know the language.

Table 1. Language proficiency

\begin{tabular}{|l|c|c|c|c|c|c|}
\hline Level of proficiency & \multicolumn{4}{|c|}{ The Tatars } & \multicolumn{3}{c|}{ The Polish } \\
\hline $\begin{array}{l}\text { I don't know the } \\
\text { language }\end{array}$ & 19,4 & 9,7 & - & 19,4 & 9,7 & - \\
\hline $\begin{array}{l}\text { I understand it, but I } \\
\text { can not explain }\end{array}$ & 32,3 & 16,1 & - & 32,3 & 16,1 & - \\
\hline $\begin{array}{l}\text { I understand it and } \\
\text { can hardly explain }\end{array}$ & 19,2 & 38,6 & - & 19,2 & 38,6 & - \\
\hline $\begin{array}{l}\text { I understand it, freely } \\
\text { speak and read, but } \\
\text { don't write }\end{array}$ & 13,0 & 13,0 & 6,5 & 13,0 & 13,0 & - \\
\hline $\begin{array}{l}\text { I understand it, freely } \\
\text { speak, read and } \\
\text { write }\end{array}$ & 19,3 & 29,0 & 90,2 & 19,3 & 29,0 & 96,6 \\
\hline
\end{tabular}

$32.3 \%$ of Tatars and $19.9 \%$ of Poles demonstrated a good level of proficiency in the mother tongue, $51.5 \%$ of Tatars and $59.9 \%$ of Poles illustrated the passive language proficiency; $19.4 \%$ of Tatars and $16.7 \%$ of Poles do not speak their mother tongue. The results of this study allow us to state dominance of the bilingual Tatars: if we take the threshold "I understand it and can hardly explain» then we can state that the $80.6 \%$ of respondents can be considered bilingual with varying degrees of knowledge of the state language, as well as $96.7 \%$ of respondents have a good command of the Russian language. Among the respondents, only $13.3 \%$ of Poles indicated a low level of proficiency in Kazakh, 96.6\% are fluent in Russian.

There is a view that Russian will retain its spread in Kazakhstan due to the requirements of economic development and the effects of globalization (Fierman, 2005). The survey results show the decisive role of the Russian language in the development of speech activity of the respondents, and the future of its dominance in the different social and communication spheres. We analyzed the data on the basis of the language before entering school. The results demonstrate that Russian-speaking Tatars $(67.7 \%)$ was higher than the Tatarspeaking Tatars (9.7\%) and bilingual Tatars (Russian and Kazakh - 6.5\%; Tatar and Russian - 9.7\%); 96.7\% of Poles spoke Russian before entering schools.

To determine the areas of the use of Kazakh, Russian and other languages we analyzed respondents' answers to questions about the use of these languages with an indication of their use intensity (always, often, sometimes) in the following areas: a) at work (in school); b) on the market; c) in the street, and transport; d) in the family; e) watching television; f) listening to the radio; g) reading newspapers, books. 
Table 2. Characteristics of language use in various domains of communication

\begin{tabular}{|c|c|c|c|c|c|c|c|c|c|c|c|c|c|}
\hline & & & Tata & & & & & & & Polis & & & \\
\hline & & & Doma & & & & & & & Doma & & & \\
\hline a & $b$ & $c$ & $d$ & e & $f$ & $\mathrm{~g}$ & $a$ & $b$ & C & d & e & $f$ & g \\
\hline & & The & atar lo & guage & & & & & The & olish I & gquage & & \\
\hline & & & ometi & & & & & & & ometir & & & \\
\hline 6,4 & 3,2 & 6,5 & 6,5 & 6,5 & 6,5 & 12,9 & 13,3 & - & - & 6,7 & 6,7 & 13,3 & 16,7 \\
\hline & & & ofte & & & & & & & ofter & & & \\
\hline 6,5 & 3,2 & 3,2 & 45,2 & 35,4 & 12,9 & 29,0 & 6,7 & 3,3 & 3,3 & - & - & 3,3 & - \\
\hline & & & alwa & & & & & & & alway & & & \\
\hline 19,4 & 6,4 & 3,2 & 45,2 & 32,2 & 16,1 & 29,0 & 3,3 & 3,3 & 3,3 & 45,2 & 10,0 & 10,0 & 10,0 \\
\hline & & The $\mathrm{K}$ & azakh & nquage & & & & & The $\mathrm{K}$ & zzakh & nquaqe & & \\
\hline & & & ometi & & & & & & & ometir & & & \\
\hline 9,7 & 3,2 & 9,7 & 3,2 & 3,2 & - & 6,5 & 6,6 & 13,3 & 10,0 & - & 20,0 & 6,7 & 10,0 \\
\hline & & & oftel & & & & & & & ofter & & & \\
\hline 25,8 & 25,8 & 25,8 & 9,7 & 19,3 & 9,6 & 29,0 & 6,7 & 6,7 & 6,7 & - & - & 10,0 & - \\
\hline & & & alwa & & & & & & & alway & & & \\
\hline 25,8 & 25,8 & 25,8 & 12,9 & 12,9 & 6,4 & 32,2 & - & - & - & 12,9 & - & - & - \\
\hline & & The $\mathrm{P}$ & Issian & nguag & & & & & The $\mathrm{P}$ & Issian & inguag & & \\
\hline & & & ometi & & & & & & & ometir & & & \\
\hline 3,2 & 3,2 & 3,2 & - & 3,2 & 16,2 & 9,7 & - & - & - & - & 3,3 & 3,3 & - \\
\hline & & & oftel & & & & & & & ofter & & & \\
\hline 3,3 & 6,5 & 6,5 & 22,6 & 13,0 & - & - & 3,3 & 3,3 & 3,3 & - & - & - & - \\
\hline & & & alway & & & & & & & alway & & & \\
\hline 93,5 & 90,3 & 90,3 & 77,4 & 83,8 & 83,8 & 90,3 & 96,7 & 93,3 & 93,3 & 73,3 & 83,3 & 76,6 & 76,6 \\
\hline & & The & gglish & nguage & & & & & The & glish & nguage & & \\
\hline & & & ometi & & & & & & & ometir & & & \\
\hline- & - & - & - & - & 3,2 & - & - & - & - & - & 3,3 & - & - \\
\hline & & & ofte & & & & & & & ofter & & & \\
\hline- & - & - & - & 3,2 & 3,2 & - & - & - & - & - & - & - & - \\
\hline & & & alwa & & & & & & & alway & & & \\
\hline- & - & - & - & 3,2 & 3,2 & - & 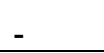 & - & - & - & - & - & - \\
\hline
\end{tabular}

The survey results indicate the dominance of the Russian language in almost all spheres.

Data on the active use of native language, determined by the formula «always» and "often», have the following features: 1) Tatar respondents: the family: $45.2 \%$ chose «always», $45.2 \%$ - «often»; watching television: $35.2 \%$ chose «always», 35.4\% -«often»; while reading newspapers and magazines: $29 \%$ of respondents chose «always», $29 \%$ - «often»; 2) Polish respondents: in the family: $45.2 \%$ of them chose «always»; watching television and listening to the radio: $10.0 \%$ chose «always»; when reading newspapers and magazines: $10.0 \%$ of respondents indicated «always». 
Active use of the state language is noted in the following areas: 1 ) among Tatars: reading newspapers, books: $29 \%$ of respondents indicated «always», $32.2 \%$ chose «often»; at work (in school) $-25.8 \%$ of them indicated «always», $25.8 \%$ chose «often»; b) in trade $-25.8 \%$ indicated «always», $25.8 \%$ - «often»; c) in the street and transport $-25.8 \%$ of them chose «always», $25.8 \%$ of them chose «often»; watching television $-12.9 \%$ indicated «always», $19.3 \%$ - «often»; in the family - $12.9 \%$ of respondents indicated «always», $9.7 \%$ - «often»; 2) among the Poles: in the family $-12.9 \%$ chose «always»; listening to the radio $-10.0 \%$ of them indicated «often»; at work (in school) - $6.7 \%$ chose «often»; b) in the field of trade $-6.7 \%$ chose «often»; c) in the street and transport $-10.0 \%$ chose «often». Survey data indicate a broader and more active use of the Kazakh language by the Tatars compared to the Poles that is probably due to genealogical relationship of Kazakh and Tatarbelonging to the Turkic languages.

Data on the active use of English are characterized by low rates: Tatars: respondents mentioned watching TV - 3.2\% - «always», 3.2\% - «often»; listening to the radio - 3.2\% - «always», 3.2\% - «often». Polish respondents indicated only passive use of English while watching TV (3.3\%).

Preference peculiarities of respondents in choosing the language of education and upbringing of children in the future are reflected in the following table.

Table 3. Language choice in training and education of children in the future (Tatars)

\begin{tabular}{|c|c|c|c|c|c|c|c|c|}
\hline \multicolumn{9}{|c|}{ Languages } \\
\hline Tatar & Russian & $\begin{array}{c}\text { Tatar, } \\
\text { Kazakh }\end{array}$ & $\begin{array}{l}\text { Tatar, } \\
\text { Russian }\end{array}$ & \multicolumn{2}{|c|}{$\begin{array}{l}\text { Tatar, } \\
\text { Russian, } \\
\text { Kazakh, } \\
\text { English }\end{array}$} & $\begin{array}{l}\text { Tatar, } \\
\text { Russian, } \\
\text { English }\end{array}$ & $\begin{array}{l}\text { Tatar, } \\
\text { Russian, } \\
\text { Kazakh }\end{array}$ & $\begin{array}{c}\text { Russian, } \\
\text { Turkish } \\
\text { Tatar, }\end{array}$ \\
\hline 16,7 & 13,3 & 3,3 & 30,3 & \multicolumn{2}{|c|}{10,0} & 20,0 & 3,3 & 3,3 \\
\hline \multicolumn{9}{|c|}{ Table 4. Language choice in training and education of children in the future (Polish) } \\
\hline Polish & \multicolumn{2}{|c|}{ Russian } & \multicolumn{2}{|c|}{ Russian, Polish } & \multicolumn{2}{|c|}{$\begin{array}{l}\text { Russian, } \\
\text { Kazakh }\end{array}$} & $\begin{array}{l}\text { Russian, } \\
\text { English }\end{array}$ & Polish, \\
\hline 13,3 & \multicolumn{2}{|c|}{43,3} & \multicolumn{2}{|l|}{23,4} & \multicolumn{2}{|c|}{10,0} & \multicolumn{2}{|l|}{6,7} \\
\hline
\end{tabular}

The revealed preferences of the respondents in choosing the language of education and upbringing of children allow us to come to the following conclusions: 1 ) the choice of Tatar and Russian (30.3\%), Tatar, English and Russian (20\%); Tatar (16.7\%) dominated among Tatars; 2) the Polish respondents expressed a preference for Russian - 43\%. It should be noted that the Kazakh language as a component of a bilingual (Tatar, Kazakh) and polylingual (Tatar, Russian, Kazakh, English, Russian, Tatar, Kazakh, Russian, Polish, Kazakh) education and upbringing of children was selected by $16.6 \%$ of the Tatars and by $10.0 \%$ of the Poles. A similar position of the Tatar language comprises $70.2 \%$, Russian - $66.9 \%$ and English - 30\%. $40.1 \%$ of respondents indicated native Polish and Russian as a component of multilingual education (Russian and Polish; Russian, Polish, Kazakh; Russian, Polish, English), English - 6.7\% among the Poles.

However, the survey results showed the presence of an opinion about the importance of and the need for knowledge of the state language $(83.9 \%$ of Tatars, $90 \%$ of Poles), indicating the growth of the demand for the Kazakh language in the society, awareness of its functional significance. $74.2 \%$ of Tatars and $83.3 \%$ of Poles believe that the acquisition of Kazakh language will help them in their professional activities. The respondents indicated English (58.1\% of Tatars and $43.4 \%$ of Poles) other languages (Arabic ( $9.7 \%$ of respondents Tatars) and Chinese (3.2\% of respondents Tatars) among the foreign languages, knowledge of which is important for professional activity.

Under the concept of ethno-linguistic vitality, presented in the study of Giles H., Bourhis R.Y., Taylor D.M., the vitality of the ethnic groups is manifested in the use of the ethnic language as an important factor of ethnic identification and preservation of ethnic and cultural identity, manifested in the socio-economic, ethnic, cultural and religious aspects (Giles, Bourhis, Taylor, 1977). This is especially important for the ethnic groups living a long period in a multicultural environment. In this regard, we have great emphasis on identifying factors contributing to the preservation of the ethnic language. 
Table 5. Factors of preservation and development of the native language

\begin{tabular}{|l|l|l|}
\hline Factors & Tatars & Polish \\
\hline Visiting Sunday schools & 25,8 & 19,9 \\
\hline Use of the native language in the family & 67,8 & 48,3 \\
\hline Communication with friends of their nationality & 38,8 & 39,7 \\
\hline Reading the fiction & 22,6 & 19,8 \\
\hline Watching TV programmes & 29,0 & 23,2 \\
\hline Reading newspapers, magazines & 22,6 & 9,9 \\
\hline Internet & & 6,6 \\
\hline Study & & 3,3 \\
\hline
\end{tabular}

The analysis results confirm the importance of the use of ethnic languages in the sphere of family relations as a factor of the greatest preservation of the native language in conditions of the predominance of the KazakhRussian bilingualism. According to the respondents, the use of the native language in the process of live communication in the family $(67.8 \%$ of Tatars and $48.3 \%$ of Poles) and friends ( $38.8 \%$ of Tatars and $43.4 \%$ of Poles) promotes to the preservation of the ethnic language. The choice of other factors in the preservation of the native language is given in descending order: watching television (29\% of Tatars and $23.2 \%$ of Poles), a visit to the Sunday school (25.8\% of Tatars and $19.9 \%$ of Poles), reading fiction (22.6\% of Tatars and $19.8 \%$ of Poles) and reading newspapers and magazines (22.6\% of Tatars and $9.9 \%$ of Poles). It should be noted that the Poles indicated the use of the native language in the Internet (6.6\%) and in the educational process (3.3\%).

\section{CONCLUSION}

These studies suggest that despite the emerging trends of language shift among respondents there is a desire to realize their own ethnic identity, the role of the mother tongue as an important symbol of the ethnic group that finds all possible support from the state.

The specific objectives identified in the «State program of functioning and development of languages in the Republic of Kazakhstan for 2011-2020» are aimed at all possible support to the preservation and development of languages of all ethnic groups in Kazakhstan. The national cultural centers in all regions of the country are making a great contribution to the preservation and development of native languages and cultures, the further consolidation of the Kazakhstan society on the principles of consent and tolerance of interethnic interaction.

In the new language policy it is a highly topical to study the processes of ethnic and linguistic identification, as it allows to designate a range of problems arising from both earlier periods in the history of the country and the socio-political and economic challenges of our time. Solving these problems is important for sustained and stable development of the country, for the further implementation of the idea of peaceful coexistence of ethnic groups living in the territory of the Republic of Kazakhstan, the preservation and development of their languages.

\section{ACKNOWLEDGEMENTS}

This research was financially supported by the Ministry of Education and Science of the Republic of Kazakhstan (Grant NO 5503/ГC4 from 02.12.2015).

\section{REFERENCE LIST}

Fierman W. (2005). "Kazakh Language and Prospects for Its Role in Kazakh «Groupness»". - USA: Ab Imperio. George Mason University - p. 393-423 http:// mason.gmu.edu/ cenasia/Fierman.pdf>.

Giles H., Bourhis R.Y., Taylor D. M. "Towards a Theory of Language in Ethnic Group Relations". In Giles, H. (1977). Language, Ethnicity, and Intergroup Relations. London: Academic Press. p. 307-348.

"The State Program of Functioning and Development of Languages for 1998-2000 Years". (2002). Terminological Collection. Almaty, p. 213-243.

"The State Program of Functioning and Development of Languages for 2001-2010 Years". (2005). Main Legislative Acts on Languages in the Republic of Kazakhstan. Almaty: Yurist, p. 18-29.

The State Program of functioning and development of languages for 2011-2020 years (2011). Astana. 
Zhuravleva, Ye. A. Piontek, T. (2013). The Polish Language in Kazakhstan: Experience and Prospects of Study at Higher Educational Institutions (Польский язык в Казахстане: опыт и перспективы изучения В высших учебных заведениях). Slavyanskie yazyki $v$ etnokulturnom prostranstve Kazakhstana (Славянские языки в этнокультурном пространстве Казахстана): collection of materials of the round table. Eds.: Buribayeva, M.A., Makhambetova, A.A., Shakhin, A.A. Astana, p. 6471.

"Law «On languages in the Republic of Kazakhstan»". (1999). Language Policy in the Republic of Kazakhstan: Collection of Documents. Astana.

Zamaletdinov, R.R. (2015). About realization of the project "Kayum Nasyri Institute" (О реализации проекта «Институт Каюма Насыри»). Creative legacy of the Enlightenment writers of the Turkic world: Materials of International scientific-practical conference. Kazan, p. 5-6.

"The Constitution of the Republic of Kazakhstan". (2002). Terminological Collection. Almaty.

"The Cencus of the Republic of kazakhstan of 2009. Brief summary". (2010). Astana.

Suleimenova, E.D. (2011). Language Processes and Policy (Языковые процессы и политика). Almaty; Kazak Universiteti.

Languages of the Peoples of Kazakhstan. Sociolinguictic Reference (Языки народов Казахстана. Социолингвистический справочник). (2007). Eds. Suleimenova, E.D., Shaimerenova, N.Zh., Akhanova, D.Kh. Astana: Arman PV. 